\title{
PROPOSAL OF A RATING SYSTEM: FOR A TOURISTIC GREEN COMMUNITY IN EGYPT
}

\author{
Gihan Mosaad ${ }^{1}$, Nour Reda Darwish ${ }^{1}$ and Khaled Tarabieh ${ }^{2}$ \\ ${ }^{1}$ Architecture and environmental design, Arab Academy for Science, Technology and Maritime Transport, \\ Alexandria-Egypt, \\ ${ }^{2}$ American University of Cairo, Cairo, Egypt
}

\begin{abstract}
Sustainable design becomes mandatory as a result of environmental requirements as it improves sustainability in planning at the same time. Rating systems has started to be a tool to manage and asses the performance in many countries in the world. Furthermore the lack of a community rating system in Egypt has affected the cities and tourism potential as well, knowing that the Egyptian touristic sector is a rapidly growing industry. To manage the performance of the touristic communities, a rating system applicable in Egypt was developed. The findings of the research suggest that the customized applicable rating system in touristic cities has great resiliency within the existing local community. The aim of the paper is to present a new custom rating system to reduce the environmental load of the tourist community in Egypt. The research aim to focus on the investigation of livable community performance assessment for touristic cities to set a new criterion that follow the guidelines of site and urban development, green infrastructure, efficient energy, green transportation and sustainable tourism while protecting human's rights. This paper sets a new proposal of an Egyptian rating system to achieve better environmental, social, economic and touristic performance of communities. The research objective is to encourage the resort operators and developers to utilize green standards, evaluate options and assess the level of their touristic communities.
\end{abstract}

\section{Keywords: Rating System, Communities, Green Touristic Communities, Environmental Community, Tourism, Touristic Cities.}

\section{Introduction}

The paper explain in general the definition of a rating system based on literature review to prove when it's highly recommended to use a rated program with certain principles and guidelines. First a comparative analysis is done between different community rating systems in order to achieve the principles and optimum strategies of a rating system that suits the Egyptian communities. Second the paper will discuss the flexibility of the communities in touristic cities with the investigation of some examples. Moreover it covers the sustainable development background, the community resilience elements and the role of the local government towards sustainable planning development. The findings of the research suggest that a sustainable community development in the tourist spots will contribute to an improved resilience in the tourism sector. Some strategies are needed to ensure the sustainable development in touristic cities and to sustain the local community resilience and this through the guidance of assessment tools, rating systems combined with the theories of eco neighborhoods to ensure the quality of a livable community. Third part At the end ,a comparative table is done between several known rating systems. The three previous stages were examined and illustrated in three matrix tables; theories of sustainable communities, Strategies of sustainable tourism and community rating systems to a achieve the new customized community rating system for Egypt.

\section{HISTORICAL BACKGROUND}

During the last 15 years, there has been a regional trend in developing and applying green ratings systems across the world in several hot climate countries. Such systems have been or 
are developed in an attempt to follow the international green movement. Moreover the loss of urban design strategies and principles has become more noticeable the last 5 years in the countries of revolutions due to the political situation in the Middle East. Egypt was one of those unstable developed countries where sustainable development was ignored, as well as lack of the future planning of communities and livable neighborhoods. These issues have affected the citizens' economic and environmental aspects of life. On the other hand, Green building rating systems are increasingly gaining attention in the building industry in the Middle East noticing that each rating system, whether in the Middle East or international, is designed to suit the environment for which it was designed. (Attia, 2014)

Furthermore the Egyptian government targeted tourism as primary sector to be developed and this explains the huge significance and income derived from tourism. Nearly $40 \%$ of the energy usage in Egypt is residential which exceeds the 35\% total consumption of energy by industry (EEHC, 2009)

The challenge is sustainable tourism development in Egypt since the residential sector is not efficient as shown earlier. Therefore an applicable rating system and guidance program designed to suit the local environment is the best technique to control sustainability management in Egyptian communities in touristic cities. The target of this research is to evaluate existing rating systems for the development and measurement of sustainable communities in the world. The paper aims to examine those problems, by studying and analyzing different existing rating systems of communities in the Middle East and worldwide, and then focus on theories of eco neighborhoods to achieve the suitable applicable rating system for communities in Egypt. The paper will go through the strengths and weaknesses as well as the elements of success and failure to improve the livable communities in touristic cities as well as the tourism industry and potential.

Recently the ministry of tourism started by issuing and legalizing "the green star rating system" which is a rating system and program to improve the environmental performance of the hotels and resorts and competitiveness of the Egyptian hotel industry, however to promote and continue the cycle of the environmental management system, there is a need to have a rating system that controls the whole community around each rated hotel and resort. Having the whole community under certain environmental programs will solve and help the touristic city to improve its performance and potential. Since that the main problem of the rated and certified hotels and resorts is in the lack of cooperation between; applying the mandatory requirements of the "green star hotel" inside and outside the organization and the government that doesn't have specific environmental guidelines to protect its surroundings from the other side. (Green Star Hotel, 2016)

However, the problem with most emerging rating systems is that they imitate the most known such as LEED or BREEAM rating systems and are not enough adapted to local environmental, cultural, historical, societal and economic context. (Attia, 2014)

\section{Research design and methodology}

The paper explains, compares and presents customized rating system and recommendations to improve the questioned rating systems of community design and remind designers with the principles and strategies of sustainable design in urban development that goes beyond the existing rating systems in hot climates. These are the principles used in the Matrix table of sustainable communities:

- Sanborn principles of sustainability

- Department of Communities and Local Government

- Santa Monica

- Greening USA

- Framework of Andres Duany, Elizabeth Plater-Zyberk

- The design features Zoning codes of Huntersville

- British design codes

- Tourism in Tanzania, applicability of criteria in touristic community

These are the Principles and examples of the tourism sustainability

- Guidelines of the sustainable communities in Tanzania

- Ramsar, Iran; an example shows the relationship between tourism and community:

- Principles and guidelines based on the literature review 


\section{STRATEGIES OF SUSTAINABLE COMMUNITIES \\ 4.1.Achieving sustainability in the community}

There are as many definitions of sustainability and sustainable development, however all the definitions share a common concern for: Living within the limits, understanding the interconnections between economy, society, and environment, and equitable distribution of resources and opportunities. (Fadli, october, 2014)

A great community and neighborhood fabric is built to stand the test of time by responding to its context and climate. It is made up of a range of elements with a fine network of weaving paths and pedestrian-friendly streets throughout to enhance connectivity and encourage walking and cycling. It is easy to navigate and contains open spaces for meeting, relaxing and playing. It contains high quality, sustainable homes that contribute to the identity of the neighborhood. Throughout, facilities are thoughtfully located to meet the needs of the residents. This combination works to create a dynamic, vibrant and cohesive atmosphere (Pearl, 2010) The community is also defined as all buildings in a given geographic area, including commercial and residential buildings and a portfolio of buildings dispersed across various geographies but linked by a single owner or set of occupants. (Managan, 2012)

\subsection{Traditional neighborhoods}

The traditional neighborhoods typology comprises a compact residential area with a variety of housing types and some supporting service and civic uses like small shops, libraries and churches. It is designed to accommodate pedestrians and public transit as well as travel by car, and like most New Urbanist designers, and New York sociologist Clarence Perry before us, we base the size of neighborhoods on the $1 / 4$ mile measurement as the distance the typical adult can walk from center to edge in approximately five minutes. Completing the circle with this radius creates an area of approximately 125 acres (50 hectares) and comprises about 1000 homes at an average density of 8 dwellings per acre (52 persons per hectare). This figure anticipates a range of dwelling types from some single-family houses on medium-sized lots (1/3 acre) or larger (1/4-1/8 acre) plus town-homes and apartments and computes to an average population of about 2600 residents. The American Neighborhood is different than the European cities as per Perry 5000 residents living in his neighborhood. (Walters, Designing Commuity, 2007)

\subsection{Guidance and strategies for connecting several eco neighborhood to achieve sustainable community}

Walkable Neighborhood Centers are a fundamental and necessary component of sustainable urbanism, but how we structure them together will ultimately determine the effectiveness of The New Urbanism Neighborhoods should be clustered to form cities and towns based on transit to deliver on the promise of sustainable development don't segregate community from commerce, as Perry seemed originally to advocate. available on 15/10/2015)

Back to history, the planner Perry had a concept is the importance of cohesive neighborhoods as moral units of a city; moreover he created the idea of having the neighborhood unit as the fundamental unit of city planning. For the first time in 1929 Perry wrote for 'the regional plan of New york' the value of high quality urban design in developing the good spirit and character of a neighborhood, and created the first layout plan of a typical neighborhood. Every existing community has some features that others can learn from as well as many challenges to be addressed. For any given place, the task for professionals is to develop creative strategies and processes that will work within the local context and with its constituencies to improve long-term human and ecological welfare. (wheeler, 2009)

\section{TOURISM}

\subsection{Relationship between sustainable communities and touristic cities}

Tourism can be seen in 2013 by Pisiran and Xiao; "as a way to aid in generating income for the communities". (Amir et al, 2014) and so, one of the strategies for the community to achieve better living conditions. The main idea is for the community to create a project that presents a sustainable development and promote the relationship between local community and visitors. To develop a tourism product as such, the core characteristic is to incorporate hotel management, tourism management, food and beverage and complementary services all together and not to forget other subsystems such as infrastructure, health, education and environment of the community. Therefore, how the whole community partakes in the 
development of an area is important to widen a tourist destination. This is because tourism planning will affect the whole community. For example, the awareness of tourism is based on the local community's attitude and their evaluation on the environment, infrastructure and events, and the degree of involvement by the local community exerts a strong influence on the tourist's experience (Amir et al, 2014). Communities are likely to suffer from traffic congestion, increasing crime rates, waste water generation and increasing cost of living. Though the local population's attitudes toward tourism are important given the argument that a happy community is more likely to support tourism development and welcome tourists. Due to the fact that different communities have different cultures and traditions, tourism development leaves different effects on them. This issue, especially in developing countries, is more important. While most of studies have been conducted from a developed country tourism context, few have been carried out from a developing world perspective. In developing countries, local community participation in the decision making process of tourism development has often been lacking and in the decision-making process is always limited or sometimes marginalized. Cater in 1994 highlights the need for local community involvement in planning and managing tourism, particularly in the context of developing countries. (Eshliki \& Kaboudi, 2011)

The following rating system is an example of applied rating system in Egypt that control and guide the sustainability in hotels and resorts. The Green Star Hotel program act to protect Egypt's natural wealth. It's a national certification and capacity building program developed under the patronage of the Egyptian Ministry of Tourism to supports and hotels interested in improving their environmental performance and social standards. The customized certification distinguishes hotels that demonstrate sustainable environmental management through compliance with a carefully designed standard. The program is also recognized by the Global Sustainable Tourism Council (GSTC) (Green Star Hotel, 2016)

In fact, community participation in tourism development does not only relate to the decision making process and the benefits of tourism development, but also regarded integral to sustainable tourism. Community is the most important party, since it is they who will be most affected either positively or negatively by tourism planning and development.

Nzama in 2008 mentioned that "There is a strong positive relationship between the extent of the community in tourism development and their perceptions towards an increase in tourism development". Interactions between community and tourists can impact positively in terms of creating opportunities, bringing societal peace, integration of different cultures and negative manners in the form of associated problems. Finally, Tourism can improve the quality of life in an area by increasing the number of attractions, recreational opportunities, and services. Also Kumar et al in 2009 added "Tourism also offers residents' opportunities to meet interesting people, make friendships, learn about the world, and expose themselves to new perspectives". (Eshliki \& Kaboudi, 2011)

Ramsar, Iran; an example shows the relationship between tourism and community:

Ramsar is located at the distance of $291 \mathrm{~km}$ from Tehran, the capital of Iran. This city is among the most important coastal tourism destinations in Iran. Because of having good climate and enjoying three environmental potentials of mountains, flatland and sea, Ramsar city is in a proper condition for coastal tourism development. The survey instrument used in this study was a structured questionnaire. The section contained questions relating to the demographic characteristics. The second part was related to cultural, social, economic and environmental items of tourism.. (Eshliki \& Kaboudi, 2011)

Analysis of the five factors that affect the tourism:

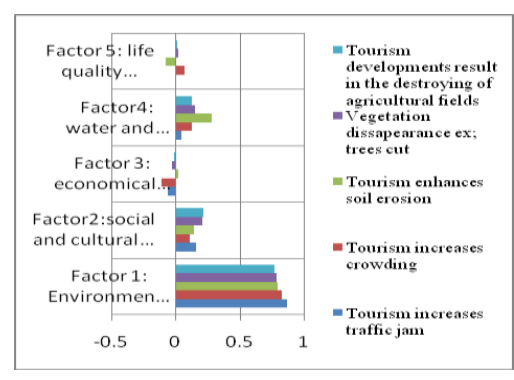

Figure 1: Environmental Destruction:

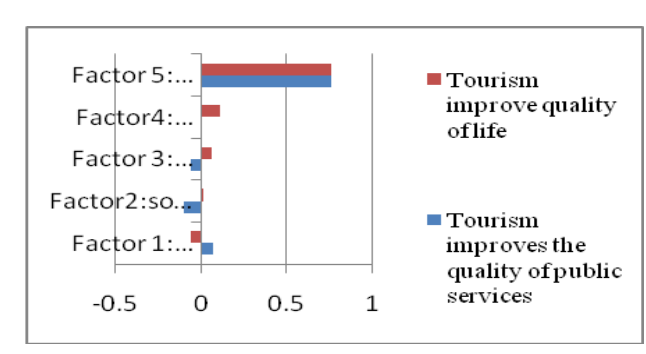

Figure 2: Life quality improvement: 


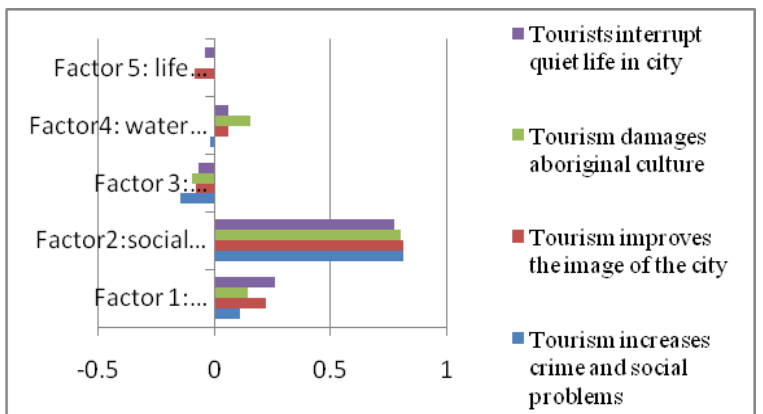

Figure 3: Social and cultural effects

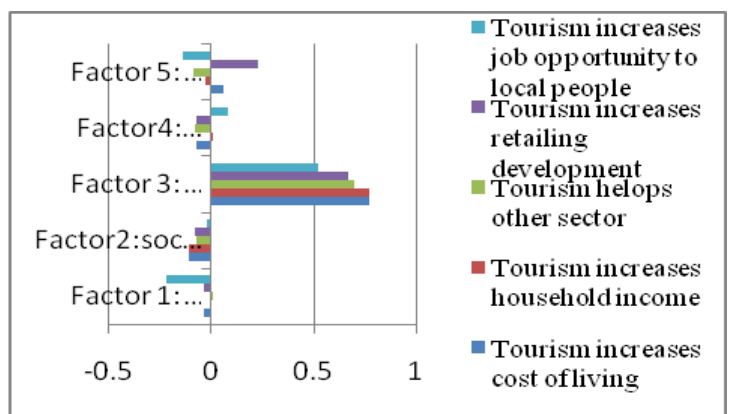

Figure 4: Economical effects

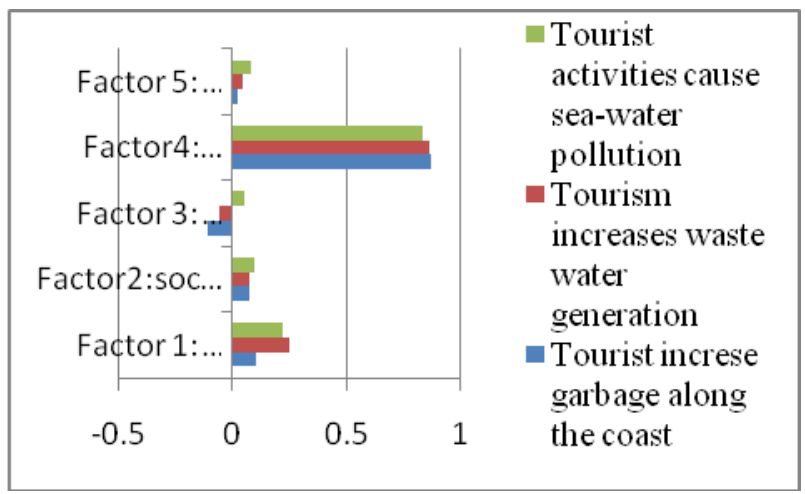

Figure 5: Water and coast pollution: Source: Researcher

\subsection{Strategies of eco communities in touristic cities}

Tourism has long been recognized as a community and economic development strategy to bring in revenues. As one of the fastest growing industries in the world, many communities are seeking ways to tap into this vast and productive industry to capture local community and economic development benefits. Moreover at the end, the research will demonstrate that when applying community rating system in touristic cities will guide towards tourism-based development. World travel and tourism council mentioned in 2005: "Tourism is considered the largest economic activities in the world with an estimated 200 million jobs worldwide and accounting for over 10 percent of global gross domestic product. Tourism also accounts for nearly 12 percent of all consumers spending, as in both developed and developing countries, it is one of the fastest growing industries in the world for all sizes of communities on the continuum from rural to urban". (Chhabra, Deepack; Phillips, Rhonda, 2009)

\subsection{Community approach to pursue a tourism-based development}

Sustainable community in tourism: "One of the most encouraging developments in the travel industry is that 'responsible tourism' has become a buzzword, something we all want to sign up to, but it has been used far too loosely and it's time to draw breath and work out just what it all means and how we can adopt it. Incorporating sustainability into the travel business is in the interest of everyone - not least the industry - by preserving the environments and cultures that we all want to continue to enjoy." Mark Ellingham, Founder - Rough Guides

Inskeep 1991: There are several compelling reasons; "tourism can provide both direct and indirect economic benefits, tourism can generate various social/cultural benefits and tourism can help achieve environmental conservation objectives". (Chhabra, Deepack; Phillips, Rhonda, 2009)

On the other hand tourism can negatively impact communities on all three of these fronts economic, social/cultural and environmental through projects or programs that are poorly designed and implemented without proper planning and consideration of impact result in negative outcomes. Tourism-based development that is too successful may result in undesirable outcomes such as stressing infrastructure limits or causing conflicts between visitor and resident population. Yet despite these concerns, tourism can be a beneficial development strategy for communities when approached correctly. Also Inskeep added that "careful planning will allow for future flexibility of new development and revitalization of 
older tourism areas". (Inskeep, 1998). Moreover successful planning strategy "goes far beyond schemes to maximize profits and therefore should include a detailed, on the ground outline so as to determine how each of the factors affecting the success of a tourism destination should be developed. (Goeldner and Ritchie, 2006) In brief, previous literature suggests the following objectives for sustainable tourism development: Formulate a framework to enhance local resident quality of life, develop multiple-use infrastructure and recreational facilities which cater to locals and tourists alike, ensure appropriate developments that are reflective and sensitive to the features unique to the area, take the cultural, social and economic values of the host community into consideration, and optimize visitor satisfaction. (Chhabra, Deepack; Phillips, Rhonda, 2009)

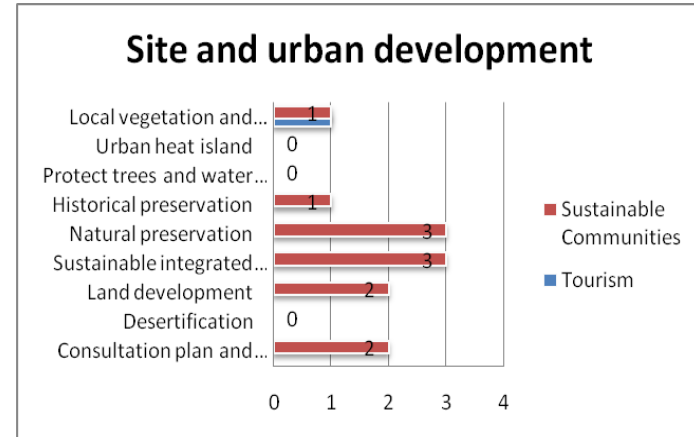

Figure 6: site and urban development

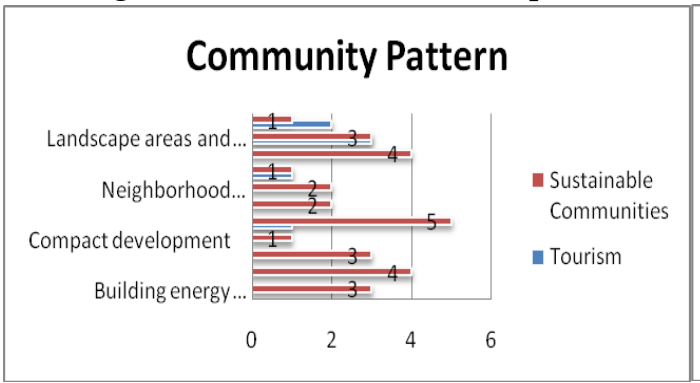

Figure 8

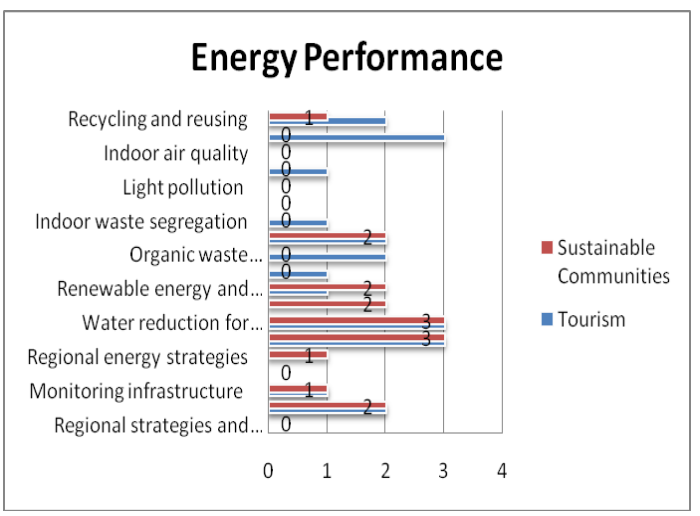

Figure 10

\section{Transportations}

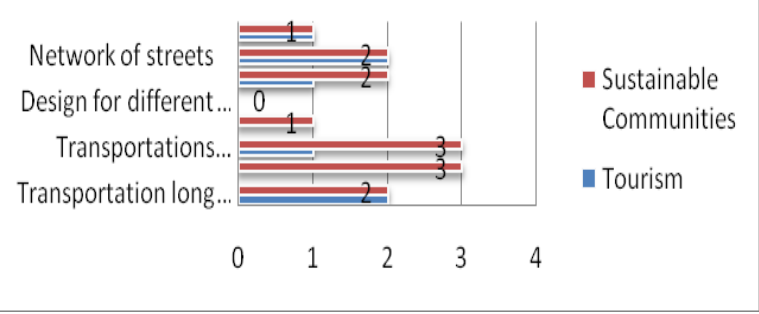

Figure 7:

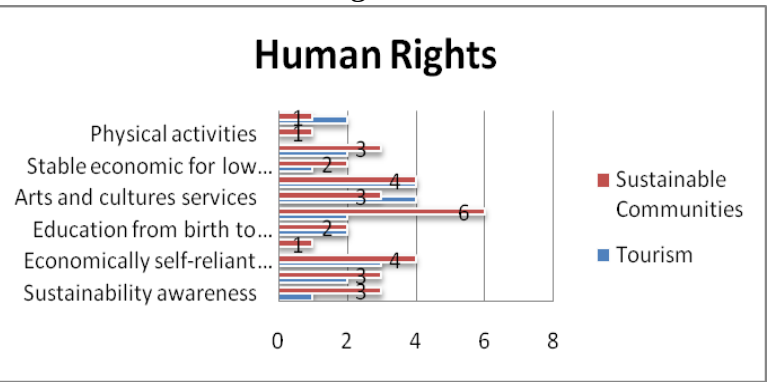

Figure 9

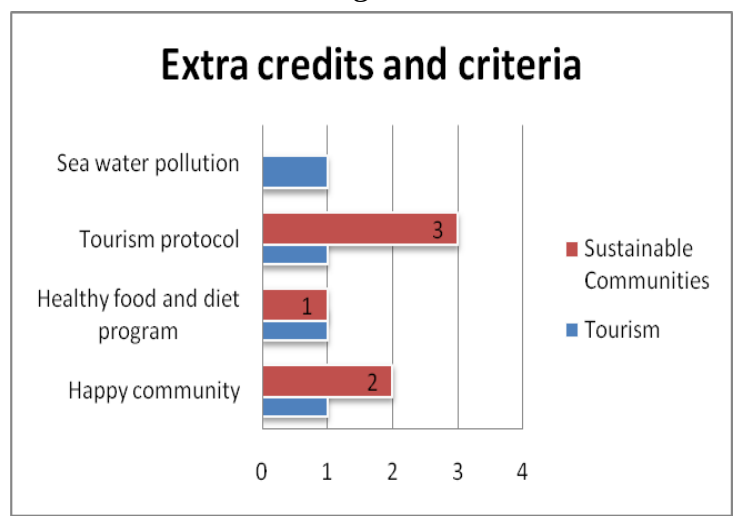

Figure 11 
PROPOSAL OF A RATING SYSTEM: FOR A TOURISTIC GREEN COMMUNITY IN EGYPT

Table 1: shows the principles of sustainable communities

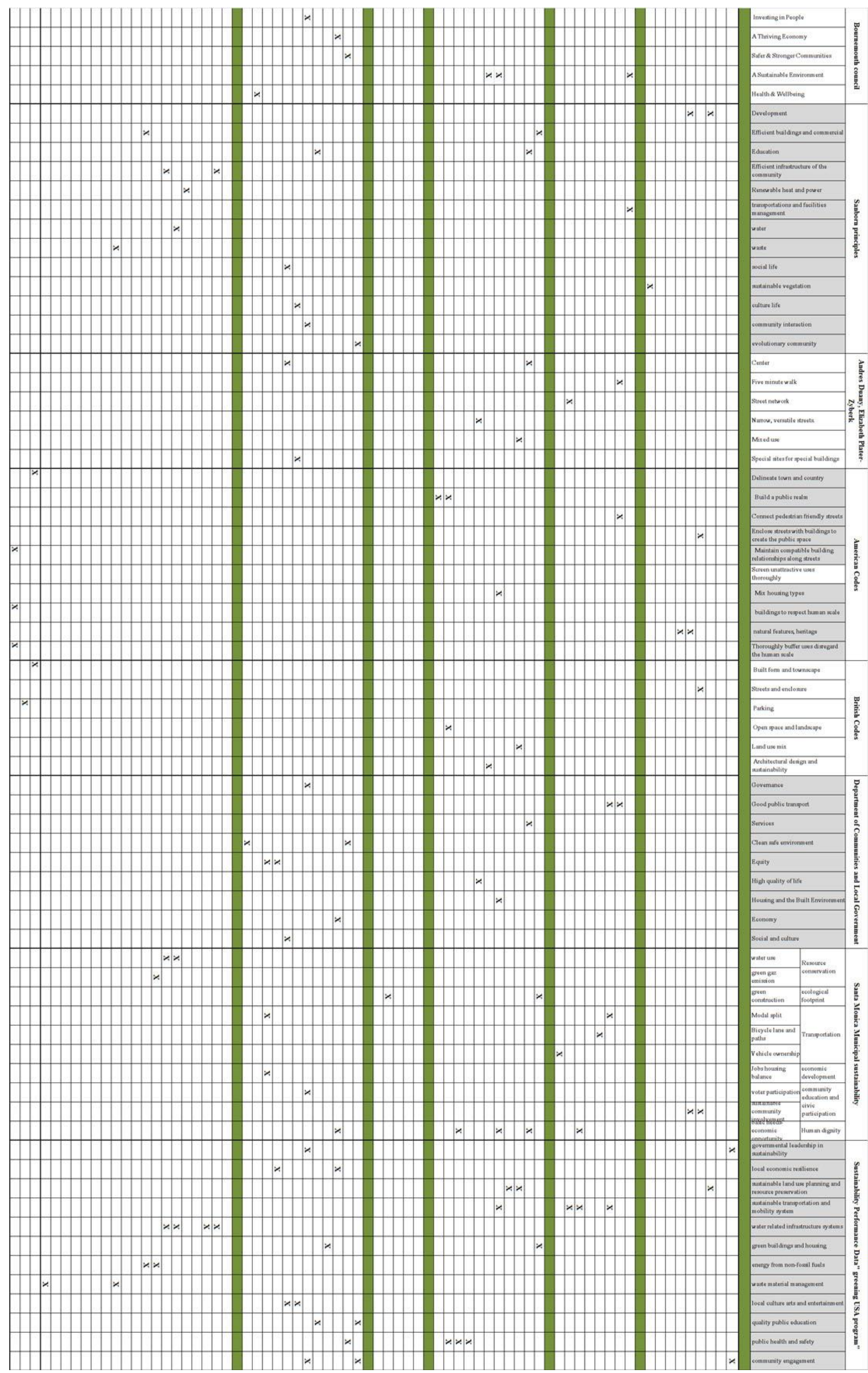


Table 2: shows the principles of sustainable tourism develonments

\begin{tabular}{|c|c|c|c|c|c|c|c|c|c|c|c|c|c|c|c|c|c|c|c|c|c|}
\hline & Princi & des of & touris & & & & & & & & & & & & Tanzani & aia sust. & tainabl & ble com & mmanit & ity tour & urism \\
\hline & & & & & & & & & & & & & & & & & & & & & \\
\hline Common keys of sustainabilty in Tourism & $\overline{\bar{z}}$ & $\stackrel{\tilde{z}}{\bar{z}}$ & $\hat{\mathbf{z}}_{0}^{m}$ & 范 & $\stackrel{n}{\grave{z}}$ & $\begin{array}{l}\stackrel{b}{z} \\
\stackrel{0}{0}\end{array}$ & 产 & 立 & $\hat{\bar{z}}$ & $\frac{2}{\bar{z}}$ & 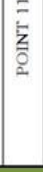 & $\mid \begin{array}{l}\frac{2}{z} \\
\bar{z} \\
\frac{2}{2}\end{array}$ & & & 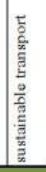 & 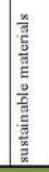 & 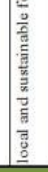 & 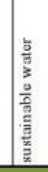 & 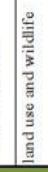 & 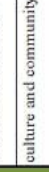 & 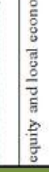 \\
\hline $\begin{array}{l}\text { Site and urban developmeut } \\
\end{array}$ & & & & & & & & & & & & & & & & & & & & & \\
\hline Consultation plan and management & & & & & & & & & & & & & & & & & & & & & \\
\hline Desertification & & & & & & & & & & & & & & & & & & & & & \\
\hline Land development & & & & & & & & & & & & & & & & & & & & & \\
\hline Sustainable integrated development & & & & & & & & & & & & & & & & & & & & & \\
\hline Natural preservation & & & & & & & & & & & & & & & & & & & & & \\
\hline Historical preservation & & & & & & & & & & & & & & & & & & & & & \\
\hline Protect trees and water bodies & & & & & & & & & & & & & & & & & & & & & \\
\hline Urban heat island & & & & & & & & & & & & & & & & & & & & & \\
\hline Local vegetation and food production & & & & & & & & & & & & & & & & & & & & & \\
\hline $\begin{array}{r}\text { Transportations } \\
\end{array}$ & & & & & & & & & & & & & & & & & & & & & \\
\hline Transportation long sustainable plan & & & & & & & $\mathrm{x}$ & & & & & & & & & & & & & & \\
\hline Walkability & & & & & & & & & & & & & & & & & & & & & \\
\hline Iransportations facilities and services & & & & & & & & & & & & & & & & & & & & & \\
\hline Bikeability & & & & & & & & & & & & & & & & & & & & & \\
\hline Design for different able and seniors & & & & & & & & & & & & & & & & & & & & & \\
\hline Safe and affordable transportations & & & & & & & $\mathrm{x}$ & & & & & & & & & & & & & & \\
\hline Network of streets & & & & & & & $\mathrm{x}$ & & & & & & & & & & & & & & \\
\hline Green transportations and services & & & & & & & & & & & & & & & $\mathrm{X}$ & & & & & & \\
\hline Community Pattern & & & & & & & & & & & & & & & & & & & & & \\
\hline Bulding energy performance & & & & & & & & & & & & & & & & & & & & & \\
\hline Basic amentities and services & & & & & & & & & & & & & & & & & & & & & \\
\hline Mixed use & & & & & & & & & & & & & & & & & & & & & \\
\hline Compact development & & & & & & & & & & & & & & & & & & & & & \\
\hline Housing affordability and diversity & & & & & & & $\mathrm{x}$ & & & & & & & & & & & & & & \\
\hline Local vernacular & & & & & & & & & & & & & & & & & & & & & \\
\hline Neighborhood connectrinty & & & & & & & & & & & & & & & & & & & & & \\
\hline Recreational urban areas (special) & & & & & & & & & & & & $\mathrm{x}$ & & & & & & & & & \\
\hline Parks and open spaces for low-incomes & & & & & & & & & & & & & & & & & & & & & \\
\hline Landscape areas and parks & & & & & & & & & & & $\mathrm{X}$ & $\mathrm{x}$ & & & & & & & & & \\
\hline Hardscape area and modular pavement & & & & & & & & & & & & $\mathrm{x}$ & & & & & & & & & \\
\hline $\begin{array}{c}\text { Sustainable tourism } \\
\end{array}$ & & & & & & & & & & & & & & & & & & & & & \\
\hline Guest information desks & & & & & & & & & & & & $\mathrm{x}$ & & & & & & & & & \\
\hline Local traditional industrial & & & & & & & & & & & & $\mathrm{xX}$ & & & & $\mathrm{x}$ & & & & & \\
\hline Connectivity between attractions and hotels & & & & & & & & & & & & $\mathrm{x}$ & & & & & & 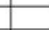 & & 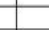 & \\
\hline Green star hotels rating system & & & & & $\mathrm{X}$ & & & & $\mathrm{X}$ & & & & & & & & & & & & \\
\hline Education and tourism development program & & & & $\mathrm{x}$ & & $\mathrm{xx}$ & & & & & & & & & & & $\mathrm{x}$ & & & & \\
\hline Humans Rights & & & & & & & & & & & & & & & & & & & & & \\
\hline Sustainability awareness & & & & & & & & & & & & & & & & & $\mathrm{x}$ & & & & \\
\hline Safety and security & & & & & & & $\mathrm{x}$ & & & & & & & & & & & & & & \\
\hline Economically self-reliant community & & & $\mathrm{x}$ & & & & & & & & & $\mathrm{x}$ & & & & & & & & & $\mathrm{x}$ \\
\hline Green market development & & & & & & & & & & & & & & & & & & & & & \\
\hline Education from bisth to adulthood & & & & & & $\mathrm{xx}$ & & & & & & & & & & & & & & & \\
\hline Participation in local decision making & $\mathrm{x}$ & $\mathrm{X}$ & & & & & & & & & & & & & & & & & & & \\
\hline Arts and cultures services & & & & & & & & & & $\mathrm{x}$ & & $\mathrm{x}$ & & & & & & & & $\mathrm{x}$ & $\mathrm{x}$ \\
\hline Social and cultural intiativives & & & & & & & & & & $\mathrm{x}$ & & $\mathrm{x}$ & & & & & & & & $\mathrm{x}$ & $x$ \\
\hline Stable economic for low incomes & & & & & & & & & & & & & & & & & & & & & $\mathrm{X}$ \\
\hline Employment opportunities & & & & & & & & & & $\mathrm{x}$ & & - & & & & & & & & & $\mathrm{x}$ \\
\hline Physical activities & & & & & & & & & & & & & & & & & & & & & \\
\hline Health strategy to reduce hazards & & & & & & $\mathrm{x}$ & & & & & & 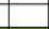 & & & & & & 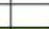 & & & 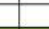 \\
\hline Energy performance & & & & & & & & & & & & & & & & & & & & & \\
\hline Regional strategies and active design & & & & & & & & & & & & & & & & & & & & & \\
\hline Efficient infrastructure & & & & & & $\mathrm{x}$ & & & & & & $\mathrm{x}$ & & & & & & & & & \\
\hline Monitoring inffastructure & & & & & & & & & & & & & & & & & & $\mathrm{x}$ & & & \\
\hline Access to operation and maintenance & & & & & & & & & & & & & & & & & & & & & \\
\hline Regional energy strategies & & & & & & & & & & & & & & & & & & & & & \\
\hline Regional water strategies & & & & & & & $\mathrm{x}$ & & & & & & & & & & & $\mathrm{x}$ & & & \\
\hline Water reduction for public realm & & & & & & & $\mathrm{x}$ & & & & & & & & & & & $\mathrm{x}$ & & & \\
\hline Green house gas $\mathrm{CO} 2$ emission reduction & & & & & & & & & & & & & & & & & & & & & \\
\hline Renewable energy and passive design & & & & & & & & & & & & & $\mathrm{X}$ & & & & & & & & \\
\hline Local material & & & & & & & & & & & & & & & & $\mathrm{x}$ & & & & & \\
\hline Organic waste management & & & & & & & & & & & & & & $\mathrm{x}$ & & & & & & & \\
\hline Waste management and reuse & & & & & & & & & & & & & & $\mathrm{x}$ & & & & & & & \\
\hline Indoor waste segregation & & & & & & & & & & & & & & $\mathrm{x}$ & & & & & & & \\
\hline Waste construction and pollution prevention & & & & & & & & & & & & & & & & & & & & & \\
\hline Light pollution & & & & & & & & & & & & & & & & & & & & & \\
\hline Noise pollution & & & & & & & & & & & & & & & & & & & & & \\
\hline Indoor air quality & & & & & & & & & & & & & & & & & & & & & \\
\hline Outdoor air quality & & & & & & $\mathrm{x}$ & & & & & & & & & & & & & & & \\
\hline Recycling and reusing & & & & & & & & & & & & & & $\mathrm{x}$ & & & & & & & \\
\hline Happy community & & & & & & & & $\mathrm{x}$ & & & & & & & & & & & & & \\
\hline Healthy food and diet program & & & & & & & & & & & & & & & & & $\mathrm{x}$ & & & & \\
\hline Tourism protocola & & & & & & & & & & & & & & & & & & & $\mathrm{x}$ & & \\
\hline Sea water pollution & & & & & & & & & & & & & & & & & & & & & \\
\hline
\end{tabular}




\section{RATING SYSTEMS}

\subsection{Sustainable Rating system definitions}

The assessments of sustainability can help inform the societal discussion and influence the environmental governance towards the main objectives of sustainability. The effectiveness of an assessment system in this regards requires that it matches up well against a number of requirements, in such a way that it can be seen to be; Hopeful, Holistic, Protective, Harmonious, Participatory, and Habit forming. (Author adapted from: Hardi \& ZdanBelaggio STAMP, 2009; Brandon \& Lombardi, 2011)

Green communities are an integral part of the solution of the environmental performance of a city and to the environmental challenges facing the planet. These are some local and international community rating systems that describes the significances advances to transform to sustainable livable communities towards a sustainable planet. However each rating system has been developed to meet the following underlying principles:

- Ensure environmental quality through an accessible, holistic, and balanced measure of environmental impacts.

- Use quantified measures for determining environmental quality.

- Use best available science and best practice as the basis for quantifying and calibrating a cost-effective

- Performance standard for defining environmental quality.

- Reflect the social and economic benefits of meeting the environmental objectives covered.

- Provide a common framework of assessment that is tailored to meet the local context including regulation, climate, and sector. (BREEAM New Construction, Non-Domestic Buildings, Technical Manual.2011. (SD5073 V.2.00), P.13)

7.2. What are the rating systems used in the comparison and why choosing them?

- LEED for neighborhood development $\mathbf{v} 4, \mathbf{U S}$ : This rating system was chosen because it's the most popular rating system in the world, it's available online and its common used for architects and urban designers.

- The LEED-ND strategies guide for a sustainable solution in the neighborhoods and community design such as affordable housing, climate protection, improved public health and well planned mixed use.

- STAR COMMUNITY v1,Columbia: This system was designed to recognize sustainable communities and it measures community-scale sustainability through seven main categories. This system is different than other rating systems as it contains many categories that give more credits weight to the economy \& jobs, education arts \& community.

- IGBC pilot version, India: The Indian green building council is a rating system used in India in 2010, after having unprecedented growth in the urban population. Egypt's case is similar than the Indian one due to the lack of planning and sustainable development.

IGBC has launched IGBC townships rating system to enable the designer to apply green concepts and criteria so as to reduce environmental impacts that are measurable.

This rating system is also designed to develop green from day one on site.

- Pearls, Estidama v1.0,UAE: This rating system was the first program of its kind that is tailored to the Middle East region. Estidama is focused on the rapidly changing built environment.

The pearl rating system provides design guidance and detailed requirements for rating a project's potential performance in relation to the four pillars of Estidama: environmental, economic, social, cultural. One of the main seven categories that form pearl rating system for communities is "livable communities", this category includes more than 15 sub categories specialized for improving the quality \& connectivity of indoor and outdoor spaces of the community.

- BREEAM communities SD202-01.2012,UK: One of the most popular European rating systems started in UK and after in all Europe, it's applied in its various forms in fifty countries.

It has a version adopted for the gulf regions as BREEAM Gulf to suit the different weather and location. BREEAM rating system assists with the planning and design of medium to large scale, new communities and regeneration projects.

- QSAS, Qatar: This Rating system is customized to address the specific regional needs and environment of Qatar. The rating system is developed through extensive review of all 
international rating systems and the 'Best Mix 'combining the best methods for the 6 most established rating systems to provide a framework to benchmark sustainability of projects with respect to the issues which are important to Qatar, e.g.: desertification, scarcity of water, cultural heritage

\subsection{Understanding community rating systems and evaluation in the Middle East}

We can recognize that regional environmental challenges are the most important items to have a rating system. Each part of the world is suffering from lack of one or more resources. Countries in a desert area such as the Middle East countries are suffering from lack water resources and hot weather, which need cooling devices. However, they have plenty of energy resources. On the other hand, European countries and North America are suffering from lack of energy more than water resources, and they have cold weather, which needs warming devices. Moreover, the whole world is suffering from Global Warming Potential (GWP) and Ozone Depletion Potential (ODP). That means any region of the world will have specific credits in their rating system, which measure the environmental priorities and challenges. Besides, it will have some general credits in their program that serve the global challenges. (Abo Neama, 2012)

Moreover, the procedures of getting LEED certified, silver, gold, or even platinum is based on collecting points and achieving some very few prerequisites. After studying all prerequisites, we will find no one of them is focused on the regional environmental problems even inside the US. The problem is focused on some consultants who want to get LEED certification in the Middle East and their concern of collecting points regardless of the importance of this point to the environment. For example, having LEED AP, having bicycle racks and lockers in a desert climate which is very rare to have transportation using bicycles. That means Middle East countries should have adequate rating system, which reflects their environmental needs. (Abo Neama, 2012)

Rating systems are tools to can measure the level of sustainability that buildings can achieve. LEED is an effective sustainable tool that architects can use it for better building performance.

However, it measures based on the USA environmental challenges which are not all implemented in the Middle East region. Architects should consider the Middle East countries environmental challenges. Some of those are not mentioned in LEED. Local environmental criteria should be applied to any rating system to can be fully effective and reflect the environment of the project. Local sustainable rating systems should be applied for building permits. Authorities in Middle East countries should require architects to follow it as a mandatory requirement. Otherwise, owners will not be careful to ask architects to have sustainable buildings to protect our environment. (Abo Neama, 2012)

From this investigation; using LEED, as a sustainable rating system for any location is not the best way to reach to the sustainability level for some parts of the world. LEED credits weight reflects the need of an entire environment which is not in the Middle East region. It helps the energy efficiency and reduces the water consumption without guiding the architect towards real solutions to achieve that. On the other hand Green Pyramid as local rating system has missed some importance areas for Egyptian environment which means that it needs a lot of development to enhance its role for sustainability in Egypt.

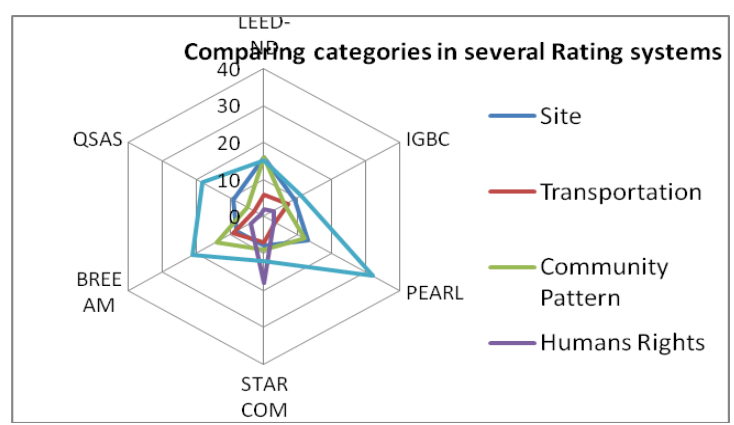

Figure 12: Charts showing the significant categories in each rating system mentioned in the previous table:

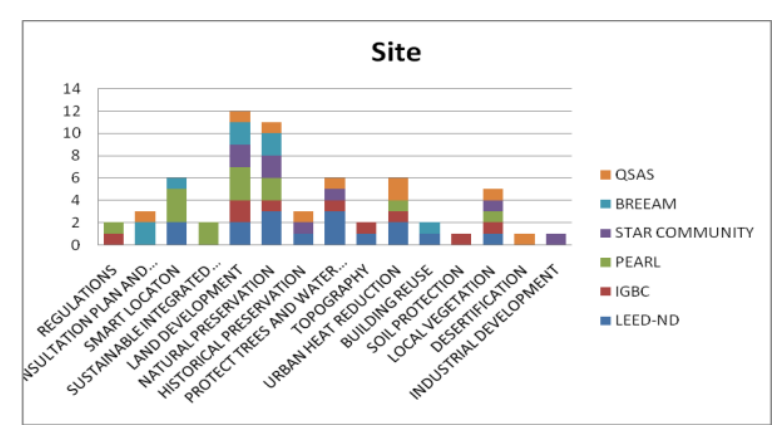

Figure 13: Comparing Site and Urban development in the investigated Rating systems: 
PROPOSAL OF A RATING SYSTEM: FOR A TOURISTIC GREEN COMMUNITY IN EGYPT

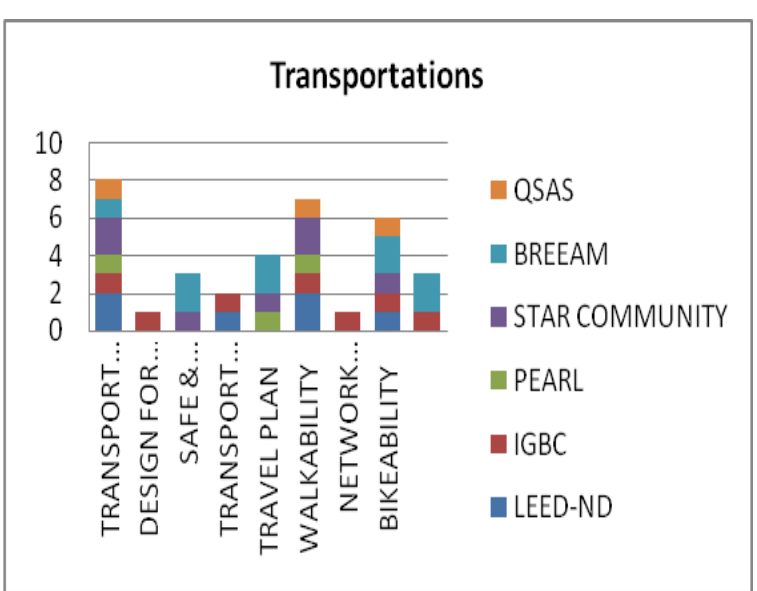

Figure 14: Comparing Transportations in the investigated Rating systems:

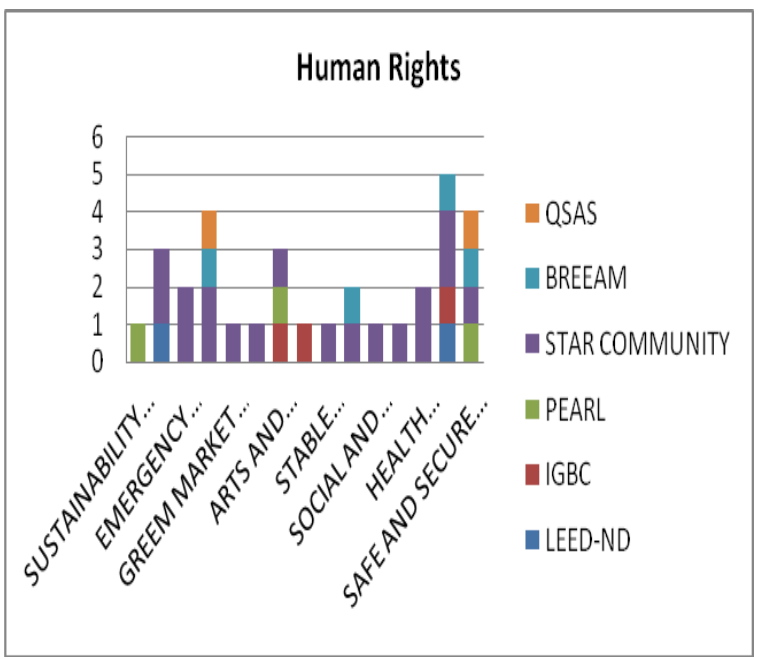

Figure 16: Comparing Human Rights in the investigated Rating systems

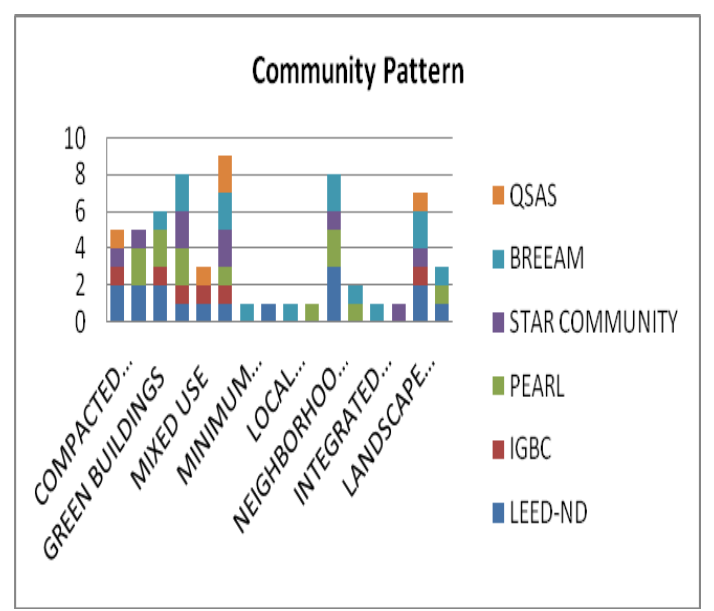

Figure 15: Comparing Community Pattern in the investigated Rating systems:

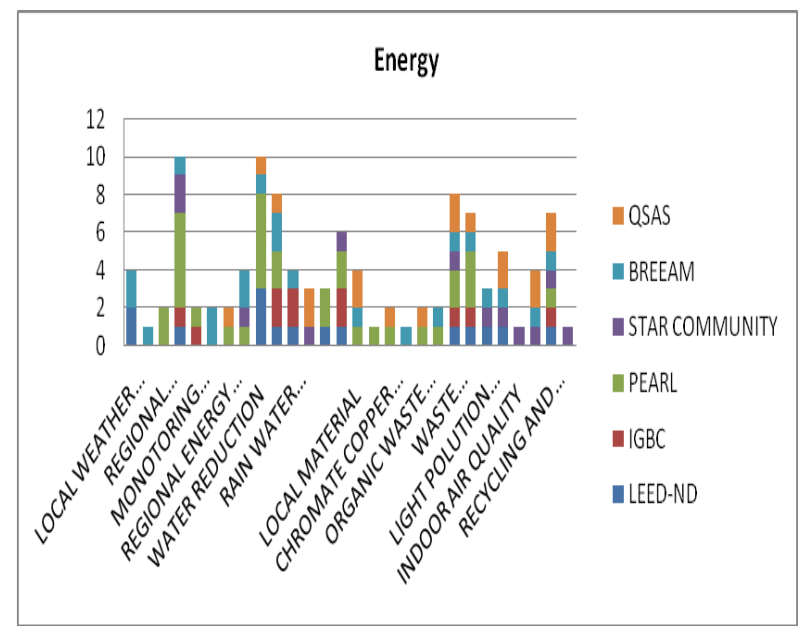

Figure 17: Comparing Energy in the investigated Rating system 
Table 3: Analyzing rating systems

\begin{tabular}{|c|c|c|c|c|c|c|c|c|}
\hline & 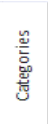 & ELEMENTS OF COMMUN ITY RATING SYSTEM & $\begin{array}{l}\sum_{1} \\
\text { ⿱ㅓㅁ }\end{array}$ & 品 & 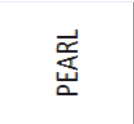 & 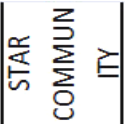 & 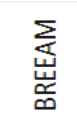 & $\frac{n}{\tilde{d}}$ \\
\hline & & REGULATIONS & & 水 & 水 & & & \\
\hline & & CONSULTATION PLAN AND MANAGEMENT & & & & & ** & * \\
\hline & & SMART LOCATON & * * & & *** & & * & \\
\hline & & SUSTAINABLE INTEGRATED DEVELOPMENT & & & **a & & & \\
\hline & & LAND DEVELOPMENT & ** * & ** & \#*\# & & & * \\
\hline & & NATURAL PRESERVATION & *** & \# & $* *$ & 来来 & 来米 & * \\
\hline & س & HISTORICAL PRESERVATION & * & & & * & & \# \\
\hline & E & PROTECT TREES AND WATER BODIES & *** $*$ & * & & * & & * \\
\hline & $\bar{n}$ & TOPOGRAPHY & * & * & & & & \\
\hline & & URBAN HEAT REDUCTION & **. & * & * & & & $* *$ \\
\hline & & BUILDING REUSE & *3 & & & & * & \\
\hline & & SOIL PROTECTION & & * & & & & \\
\hline & & LOCAL VEGETATION & * & * & * & * & & * \\
\hline & & DESERTIFICATION & & & & & & * \\
\hline & & INDUSTRIAL DEVELOPMENT & & & & * & & \\
\hline & & TRANSPORTATIONS FACLITIES AND SERVICES & * * * & * & * & ** & * & * \\
\hline & $\sum_{0}^{n}$ & DESIGN FOR DISABLED AND SENIORS SPACES & $x$ & * & & & & \\
\hline & 을 & SAFE \& AFFORDABLE TRANSPORTATIONS & & & & * & ** & \\
\hline & $\leq$ & TRANSPORTATION LONG SUSTAINABLE PLAN & * & * & & & 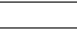 & \\
\hline & \%ั & TRAVEL PLAN & & & * & * & 胱 & \\
\hline & $\therefore$ & WALKABILITY & * * & * & * & \# & 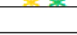 & \# \\
\hline & $\sum_{i}^{2}$ & NETWORK OF STREETS & & * & & & & \\
\hline & $\$$ & BIKEABILITY & * & * & & * & ** & * \\
\hline & & GREEN TRANSPORTATION & & * & & & 光 & \\
\hline & & COMPACTED LAND USE & ** & * & & * & & \# \\
\hline & & BUILDING ENERGY PERFORMANCE & *** & & ** $*$ & * & & 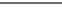 \\
\hline & $z$ & GREEN BUILDINGS & ** & * & ** & & * & \\
\hline & $\bar{\sim}$ & BASIC AMENITIES AND SERVICES & * & * & ** & ** $*$ & ** & \\
\hline & 岸 & MIXED USE & * & * & & & & * \\
\hline & 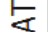 & HOUSING AFFORDABILITY AND DIVERSITY & * & * & * & ** & ** & $* *$ \\
\hline & 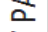 & MINIMUM SPACE STANDARS FOR HOUSING & & & & & * & \\
\hline & $己$ & UNIVERSAL DESIGN & * & & & & & \\
\hline$\geqq$ & $\overline{\bar{z}}$ & LOCAL VERNACULAR & & & & & * & \\
\hline$\vec{E}$ & 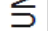 & RECREATIONAL URBAN AREAS & & & * & & & \\
\hline & $\bar{\Sigma}$ & NEIGHBORHOOD CONNECTIVITY & *** & & ** & * & * * & \\
\hline 年 & $\sum$ & GENERAL ZONING- OPEN SPACE NETWORK & & & * & 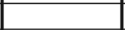 & * & \\
\hline (․ & O & INTEGRATED LOCAL PARKING & & & & & * & \\
\hline & 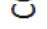 & PARKS AND OPEN SPACES FOR LOW INCOME & & & & * & & \\
\hline$\$$ & & LANDSCAPE AREAS \& PARKS & * * & * & & * & * & * \\
\hline$\simeq$ & & HARDSCAPE AREA \& MODULAR PAVEMENT & * & & * & 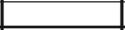 & * & \\
\hline$\sum$ & & SUSTAINABILITY AWARENESS & & & * & & & \\
\hline $\bar{z}$ & & PARTICIPATION IN LOCAL DESCION-MAKING & * & & & ** $*$ & & \\
\hline క & & EMERGENCY AWARENESS FOR NATURAL AND HUMAN HAZARDS & & & & ** $*$ & & \\
\hline$\Sigma$ & $\sim$ & ECONOMICALLY SELF-RELIANT COMMUNITY & & & & ** $*$ & \# & \# \\
\hline$\sum$ & 荓 & GREEM MARKET DEVELOPMENT & & & & * & & \\
\hline 8 & $\frac{1}{\Xi}$ & EDUCATIION FROM BIRTH TO ADULTHOOD & & & & * & & \\
\hline & $\bar{c}$ & ARTS AND CULTURES SERVICES & & * & * & * & & \\
\hline & $z$ & FACILITIES FOR WORKFORCE IN CONSTRUCTION & & * & & & & \\
\hline & 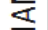 & STABLE ECONOMIC FOR LOW INCOMES & & & & * & & \\
\hline & $\sum$ & EDUCATION AND DEVELOPMENT PROGRAMS FOR WORKFORCE & & & & * & * & \\
\hline & 马 & SOCIAL AND CULTURAL RESPECT IN COMMUNITY & & & & * & & \\
\hline & & PHYSICAL ACTIVITIES & & & & * & & \\
\hline & & HEALTH STRATEGY TO REDUCE HAZARDS & & & & $* *$ & & \\
\hline & & EMPLOYMNET OPPORTUNITIES & * & * & & 类当 & * & \\
\hline & & SAFE AND SECURE COMMUNITY & & & \# & * & * & * \\
\hline & & LOCAL WEATHER CONDITIONS (US, UK) & 头㨁 & & & & ** & \\
\hline & & RESILIENCE DEVELOPMENT FOR REGIONAL CLIMATE CHANGE & & & & & * & \\
\hline & & REGIONAL STRATEGIES AND ACTIVE DESIGN & & & * & & & \\
\hline & & EFFICIENT INFRASTRUCUTRE & * & * & 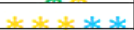 & $*$ & * & \\
\hline & & MONOTORING ENERGY USE IN INFRASTRUCTURE & & * & * 3 & & 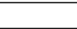 & \\
\hline & & ACESS TO OPERATION AND MAINTENANCE OF THE COMMUNITY & & & & & $* *$ & \\
\hline & & REGIONAL ENERGY STRATEGIES & & & * & & & * \\
\hline & & REGIONAL WATER STRATEGIES & & & * & * & 相 & \\
\hline & & WATER REDUCTION & ***; & & *****; & & * & * * \\
\hline & & WATER MANAGEMEMNT AND REUSE & * & *** & $* *$ & & & * \\
\hline & & RAIN WATER MANAGEMENT & * & *** & & & * & \\
\hline & & GREENHOUSE GAS EMISSION REDUCTION & & & & * & & ** \\
\hline & 2 & ACTIVE DESIGN STRATEGIES & * & & ** $*$ & & & \\
\hline & 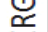 & RENEWABLE ENERGY AND PASSIVE DESIGN & * & ** & ** & * & & \\
\hline & 岁 & LOCAL MATERIAL & & & * & & 皮 & $\$ \$$ \\
\hline & ப & REUSE OR CERTIFIED TIMBER & & & * & & & \\
\hline & & CHROMATE COPPER ARSENATE TREATED TIMBER ELEMINATION & & & * & & & \# \\
\hline & & REDUCTION IN CARBON DIOXIDE & & & & & * & \\
\hline & & ORGANIC WASTE MANAGEMENT & & & * & & & * \\
\hline & & HAZARDOUS WASTE MANAGEMENT & & & * & & 水 & - \\
\hline & & WASTE MANAGEMENT AND REUSE & * & 水 & ** & * & * & \\
\hline & & WASTE CONSTRUCTION AND POLLUTION PREVENTION & * & 水 & *k-k & & * & * \\
\hline & & LIGHT POLUTION CONTROL & 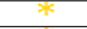 & & & * & * & \\
\hline & & NOIISE POLUUTION CONTROL & * & & & * & * & $* *$ \\
\hline & & INDOOR AIR QUALITY & & & & * & & . \\
\hline & & OUTDOOR AIR QUALITY & & & & * & * & \# \\
\hline & & RECYCLING AND REUSING & * & 水 & * & * & * & $\approx \circledast$ \\
\hline & & EFFICIENT INDUSTRIAL SECTOR & & & & * & & \\
\hline
\end{tabular}




\section{CONCLUSION:}

The paper focused on analyzing six rating systems from the most known of applicable sustainability in several communities; LEED, BREEAM, STAR COMMUNITY, IGBC, PEARL, QSAS. Identification and analysis tables and charts are done to highlight on the importance of some categories and criteria. The outcome of this chapter is a new customized rating system for communities in touristic cities applied in Egypt.

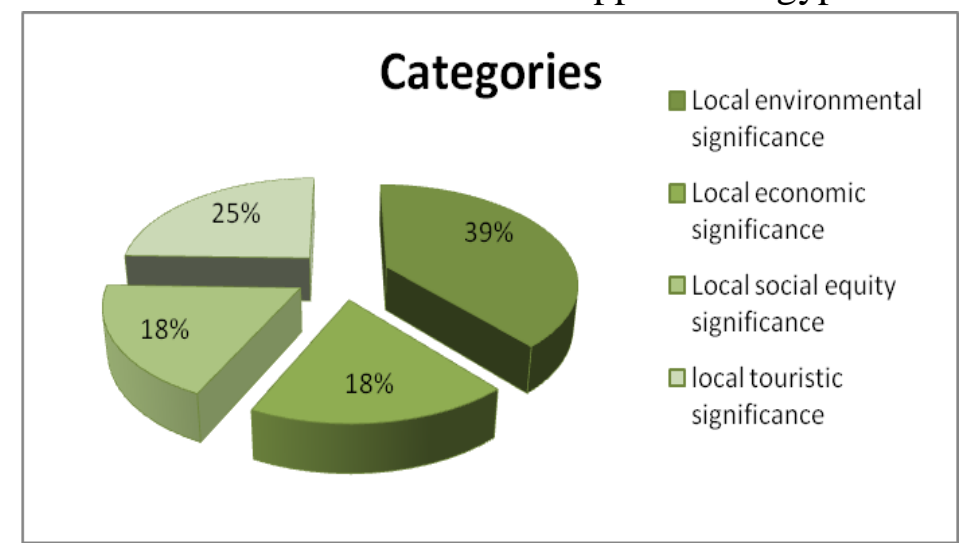

Figure 18:

Table 4: the new customized rating system

Customized community rating system for touristic cities

\begin{tabular}{|c|c|c|c|c|c|}
\hline \multicolumn{2}{|r|}{ Site and urban development } & \multicolumn{3}{|c|}{$\begin{array}{r}\text { Human Rights } \\
\end{array}$} & \multirow[b]{2}{*}{ Required } \\
\hline Mandatory & Consultation plan and management & Required & Mandatory & Sustainability awareness & \\
\hline Mandatory & Desertification & Required & Mandatory & Safety and security & Required \\
\hline Mandatory & Land development & Required & HW 1 & Economically self-reliant community & Credit \\
\hline SUD 1 & Sustainable integrated development & \begin{tabular}{|l|} 
Credit \\
\end{tabular} & HW 2 & Green market development & Credit \\
\hline SUD 2 & Natural preservation & Credit & HW 3 & Education from birth to adulthood & Credit \\
\hline SUD 3 & Historical preservation & Credit & HW 4 & Participation in local decision making & Credit \\
\hline SUD 4 & Historical preservation & Credit & HW 5 & Arts and cultures services & Credit \\
\hline SUD 5 & Urban heat island & Credit & HW 6 & Social and cultural initiatives & Credit \\
\hline SUD 6 & Local vegetation and food production & Credit & HW 7 & Stable economic for low incomes & Credit \\
\hline \multicolumn{2}{|r|}{ Transportations } & & HW 8 & Employment opportunities & Credit \\
\hline Mandatory & Long term transportation plan & Required & HW 9 & Physical activities & Credit \\
\hline Mandatory & Walkability & Required & HW 10 & Health strategy to reduce hazards & Credit \\
\hline Mandatory & Transportations facilities and services & Required & \multicolumn{2}{|c|}{\begin{tabular}{|c|} 
Energy performance \\
\end{tabular}} & \\
\hline $\mathrm{T} 1$ & Bikeability & Credit & Mandatory & Regional strategies and active design & Required \\
\hline $\mathrm{T2}$ & Design for different able and seniors & Credit & Mandatory & Efficient infrastructure & Required \\
\hline T3 & Safe and affordable transportations & Credit & Mandatory & Monitoring infrastructure energy & Required \\
\hline $\mathrm{T} 4$ & Network of streets & Credit & EP1 & Access to operation and maintenance & Credit \\
\hline T5 & Green transportations and services & Credit & EP2 & Regional energy strategies & Credit \\
\hline \multicolumn{2}{|r|}{ Community pattern } & & EP3 & Regional water strategies & Credit \\
\hline Mandatory & Building energy performance & Required & EP4 & Water reduction for public realm & Credit \\
\hline Mandatory & Basic amenities and services & Required & EP5 & Green house gas $\mathrm{CO} 2$ emission reduction & Credit \\
\hline Mandatory & Mixed use & Required & EP6 & Renewable energy and passive design & Credit \\
\hline CP 1 & Compact development & Credit & EP7 & Local material & Credit \\
\hline CP 2 & Housing affordability and diversity & Credit & EP8 & Organic waste management & Credit \\
\hline CP 3 & Local vernacular & Credit & EP9 & Waste management and reuse & Credit \\
\hline $\mathrm{CP} 4$ & Neighborhood connectivity & Credit & EP10 & Indoor waste segregation & Credit \\
\hline CP 5 & Recreational urban areas & Credit & EP11 & Light pollution & Credit \\
\hline $\mathrm{CP} 6$ & Parks and open spaces for low-incomes & Credit & EP12 & Noise pollution & Credit \\
\hline CP 7 & Landscape areas and parks & Credit & EP13 & Indoor air quality & Credit \\
\hline CP 8 & Hardscape area and modular pavement & Credit & EP14 & Outdoor air quality & Credit \\
\hline \multicolumn{2}{|r|}{ Sustainable tourism } & & EP15 & Recycling and reusing & Credit \\
\hline Mandatory & Guest information desks & Required & & Innovation & \\
\hline Mandatory & Local traditional industrial & Required & & innovative cultural and regional practices & Credit \\
\hline ST1 & Connectrivity between attractions and hotels & Credit & & innovating sustainability practices & Credit \\
\hline ST2 & Green star hotels & Credit & & & \\
\hline ST3 & Education and tourism development program & Credit & & & \\
\hline
\end{tabular}




\section{REFERENCES}

1. Abo Neama, W. (2012). Protect the Planet through Sustainability Rating Systems with. ASIA Pacific International Conference on Environment-Behaviour Studies. Giza, Cairo: Elsevier.

2. Amir et al, A. (2014). Sustainable tourism development: A study on community resilience for rural tourism in Malaysia. Asia Pacific International Conference on Environment-Behaviour Studies (pp. 116-122). Berlin: Elsevier.

3. Attia, S. (2014). The Usability of Green Building Rating Systems in Hot Arid Climates.

4. Chhabra, Deepack; Phillips, Rhonda. (2009). Tourism-based development. In R. Phillips, \& R. Pittman, An introduction to communiyt development (pp. 236-265). New York: Routledge.

5. Desha, Hargroves, \& Smith. (2007). The importance of sustainability in engineering education; a toolkit of information and teaching material. Engineering Training \& Learning Conference . Australia: The Centre for Environmental Systems Research.

6. EEHC, E. E. (2009, August 5). Electricity in Egypt. (citizens, Interviewer) Sharm Elsheikh.

7. Eshliki, S., \& Kaboudi, M. (2011). Community Perception of Tourism Impacts and Their participation in Tourism Planning. ASEAN Conference on Environment-Behaviour Studies (pp. 333-341). Indonesia: Elsevier.

8. Fadli, F. (october, 2014). New Generation Sustainability Assessment Models, Applications for urban districts and neighborhoods. World SB14 Barcelona (p. 1). Doha, Qatar: Fadli, F.

9. Green Star Hotel. (2016). Retrieved September 2014, from Green Star Hotel: http://www.greenstarhotel.org/

10. Managan, K. (2012). Net Zero Communities:One Building at a Time. Institute for Building Efficiency, ACEEE Summer Study. Washington DC: Johnson controls.

11. Pearl, R. s. (2010). Neighborhood planning, Vision 2030. Abu Dahabi: Abu Dahabi urban planning council.

12. Walters, D. (2007). Designing Commuity. Oxford: Elsevier.

13. WCED, \& Beaumont, P. (2013, June 5). 5 definitions of sustainability, the World Commission on Environment and Development. Retrieved April 6, 2015, from natural edge project, the Brundtland Commission :

http://www.naturaledgeproject.net/Keynote.aspx

14. wheeler, S. (2009). sustainability in community development. In R. Phillips, \& R. Pittman, An introduction to community development (p. 339). New York, USA: Routledge. 